\title{
Rates of Infection and Phylogenetic Analysis of GB Virus-C among Kuwaiti and Jordanian Blood Donors
}

\author{
Raed Abu Odeh ${ }^{a}$ Salem Yasin ${ }^{b}$ Gheyath Nasrallah ${ }^{c}$ Yaman Babi \\ a Department of Medical Laboratory Technology, College of Health Sciences, University of Sharjah, Sharjah, UAE; \\ ${ }^{b}$ Biological Sciences and Biotechnology, Hashemite University, Zarqa, Jordan; ' Department of Microbiology and \\ Immunology, Dalhousie University, Halifax, N.S., Canada
}

\section{Key Words}

Genotype $\cdot 5^{\prime}$-Untranslated region $\cdot$ RT/nested PCR •

Hepatitis $\mathrm{G}$ virus $\cdot$ Phylogenetic analysis

\begin{abstract}
Objectives: $\mathrm{GB}$ virus- $\mathrm{C} /$ hepatitis $\mathrm{G}$ virus (GBV-C/HGV), collectively known as GBV-C, has been reported to be associated with non-A-E hepatitis. The aim of this study was to determine the rate of infection and genotypic characteristics of GBV-C among Kuwaiti and Jordanian blood donors. Methods: A total of 334 plasma/serum samples from healthy blood donors in Kuwait $(n=130)$ and Jordan $(n=204)$ were screened using RT-PCR/nested PCR of the $5^{\prime}$-untranslated region (5'-UTR). Phylogenetic analysis was conducted by sequencing the $5^{\prime}$-UTR region of the randomly picked clones representative of the two populations. Results: The results obtained showed that the rate of GBV-C infection in healthy Kuwaiti and Jordanian blood donors was 24.6 and $9.8 \%$, respectively. Sequence analysis of the $5^{\prime}$-UTR using 4 and 6 clones from healthy Kuwaiti and Jordanian blood donors, respectively, revealed the prevalence of the European/North American genotype 2 when compared to the 6 reference genotypes in GenBank. Conclusion: GBV-C/HGV was detectable at rates relatively comparable with other regions in the
\end{abstract}

world in Kuwaiti and Jordanian blood donors, although the significance of which remains controversial. More interesting is the dominance of GBV-C genotype 2 among the two populations, which remains to be explained.

Copyright $\odot 2010$ S. Karger AG, Basel

\section{Introduction}

The new Flaviviridae RNA virus, collectively known as 'the GB virus-C/hepatitis $\mathrm{G}$ virus (GBV-C/HGV)', was isolated by two independent groups in an attempt to find an etiologic agent for non-A-E hepatitis $[1,2]$. Later studies revealed that GBV-C/HGV is widely present, with varying percentages, in healthy individuals living in the USA, Japan, Africa, as well as in the developing countries [3]. The virus was also reported in certain regions in the Middle East, including Saudi Arabia [4], Lebanon [5], Morocco [6], United Arab Emirates (UAE) [7], and Iran [8].

Deducting the complete genome sequences of GBV-C/ HGV had shown the virus to be positive-sense, singlestranded RNA virus containing about 9.4-kb nucleotides [2]. The GBV-C/HGV genome codes for a continuous open reading frame preceded by a 5 '-untranslated region

Raed Abu Odeh, $\mathrm{PhD}$

College of Health Sciences, University of Sharjah, Bldg M31, Rm 119

PO Box, 27272 Sharjah (UAE)

E-Mail abuodeh@sharjah.ac.ae

\section{KARGER \\ Fax +4161306 1234}

E-Mail karger@karger.ch

www.karger.com

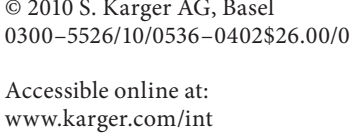


(5'-UTR), and followed by a 3 '-untranslated sequence; the open reading frame of GBV-C/HGV encodes a polyprotein, including characteristic structural and non-structural motifs [9].

Further, the virus was proven to be distantly related to hepatitis $\mathrm{C}$ virus, and consists of a genomic organization similar to that of Flaviviridae [10]. Up to the present moment, phylogenetic data compiled from various parts of the world revealed the presence of 5 distinctive genotypes of GBV-C/HGV. Type 1 is chiefly found in West Africa, type 2 in Europe, type 3 in Asia, type 4 in Southeast Asia, and finally, type 5 was found in South Africa [11-14]. More recently, a new sixth genotype has been added to the list [15].

Transmitting GBV-C is parenteral and is prevalent in patients exposed to transfused blood (and its ingredients) and in intravenous drug users. Hemodialysis patients, patients who have undergone organ transplantation, as well as post-transfusional hepatitis patients were found to carry a high percentage of this virus [3].

An earlier study resulted in the detection of the GBVC RNA in 3 out of 6 patients with non-A to E fulminant hepatitis, and accordingly was implicated as the causative agent of fulminant hepatitis [16]. Correlation between non-A to E hepatitis, or any other disease remains a controversial issue even though GBV-C RNA has been detected more often in acute and chronic non-A to E hepatitis rather than in normal controls.

An issue that remains controversial is whether GBV$\mathrm{C} / \mathrm{HGV}$ is lymphotropic. One study concluded that the virus originated from a non-hepatic site, other than that of the lymphocytes. Another study concluded that the virus was lymphotropic and reproduces mainly in the spleen and bone marrow. More convincing recent evidence supports the panlymphotropism of the virus [17, 18].

Another issue that is also controversial is the alleged association between the virus and HIV. Whereas Tillmann et al. [19] and others suggested a favorable outcome in HIV-infected patients when the GBV-C virus is present, several studies showed that favorable evidence was not decisive and needed more thorough investigation [3].

To the best of our knowledge, no previous studies have been published describing the rate of infection and phylogenetic analysis of GBV-C in Kuwait and Jordan. In this study a total of 334 blood samples from healthy blood donors representing the two populations were screened and genotyped for GBV-C RNA.

\section{Materials and Methods}

Subjects

A total of 334 serum/plasma samples from healthy Kuwaiti $(n=130)$ and Jordanian $(n=204)$ blood donors were screened for the presence of GBV-C RNA.

\section{Purification of RNA and GBV-C Detection}

GBV-C RNA was purified from serum or plasma for each sample using the High Pure Viral RNA kit (Roche, Germany) according to the manufacturer's instructions. Next, RNA was converted to cDNA using the Access Quick ${ }^{\mathrm{TM}}$ RT-PCR (reverse transcriptase-polymerase chain reaction) system (Promega, USA) at $45^{\circ}$ for $30 \mathrm{~min}$. Subsequently, cDNA was amplified, in the same tube, using a denaturation step at $94^{\circ}$ for $2 \mathrm{~min}$. This was then followed by 30 cycles of denaturation at $94^{\circ}$ for $30 \mathrm{~s}$, annealing for $30 \mathrm{~s}$ at $55^{\circ}$, and extension at $72^{\circ}$ for $30 \mathrm{~s}$. RT-PCR products were further amplified using nested PCR ( $94^{\circ}$ for $2 \mathrm{~min}$, followed by 40 cycles at $94^{\circ}$ for $30 \mathrm{~s}$; next, $55^{\circ}$ for $30 \mathrm{~s}$, and $72^{\circ}$ for $30 \mathrm{~s}$ ), using of Taq polymerase (Promega, USA). The primers used in the RTPCR/nested PCR were as follows: G58 (outer; forward), 5'CAGGGTTGGTAGGTCGTAAATCC-3'; G75 (outer; reverse), 5'-CCTATTGGTCAAGAGAGACAT-3'; G134 (inner; forward), 5'-GGTCAYCYTGGTAGCCACTATAGG-3'; G131 (inner; reverse), 5'-AAGAGAGACATTGWAGGGCGACGT-3'. The inner primers should amplify a 208 base pair (bp) region in the $5^{\prime}$-UTR of GBV-C/HGV (bases 152 through 359) [20].

\section{Identification of PCR Products, TA Cloning and}

Determination of Base Sequences

PCR products were subjected to electrophoresis in 1.5\% agarose gel, stained with ethidium bromide, and visualized under UV illumination. PCR products from a previous study [7], judged by sequencing to represent a portion of the 5 -UTR of GBV-C, were used as positive controls. Next, PCR products of about 208 bp from 6 and 4 healthy Jordanian and Kuwaiti donors, respectively, were extracted from the gel using Perfectprep ${ }^{\circledR}$ Gel Cleanup kit (Eppendorf, Germany) and were then TA-cloned into plasmid pCR4-TOPO using the TOPO TA cloning kit (Invitrogen, USA), following the manufacturer's instructions. After an incubation period of $24 \mathrm{~h}$, several separate colonies from each plate were randomly picked and grown in LB broth in the presence of $50 \mu \mathrm{g} / \mathrm{ml}$ ampicillin, and plasmids were purified using a Fast Plasmid $^{\text {TM }}$ Mini kit (Eppendorf, Germany). Plasmids were then analyzed before sequencing using EcoRI restriction digestion, which should release the cloned PCR product. Sequencing was carried out by use of the ABI 3730XL sequencer in McLab (Molecular Cloning Laboratories, San Francisco, Calif., USA; www.mclab. com). M13 reverse and forward primers were used for sequencing.

\section{Genotypic and Phylogenetic Analyses}

MEGA4 freeware was used to perform sequences alignment, using ClustalW analysis, phylogenetic, and molecular evolutionary analyses. A phylogenetic tree was constructed using the neighbor-joining method of Jukes-Cantor [21]; bootstrap resampling and reconstruction were carried out 1,000 to confirm the reliability of the phylogenetic tree.

All sequences were first confirmed to be GBV-C sequences using BLAST search. GBV-C sequences were deposited in GenBank; sequences JO01 through JO06 (accession Nos. GQ273923, 


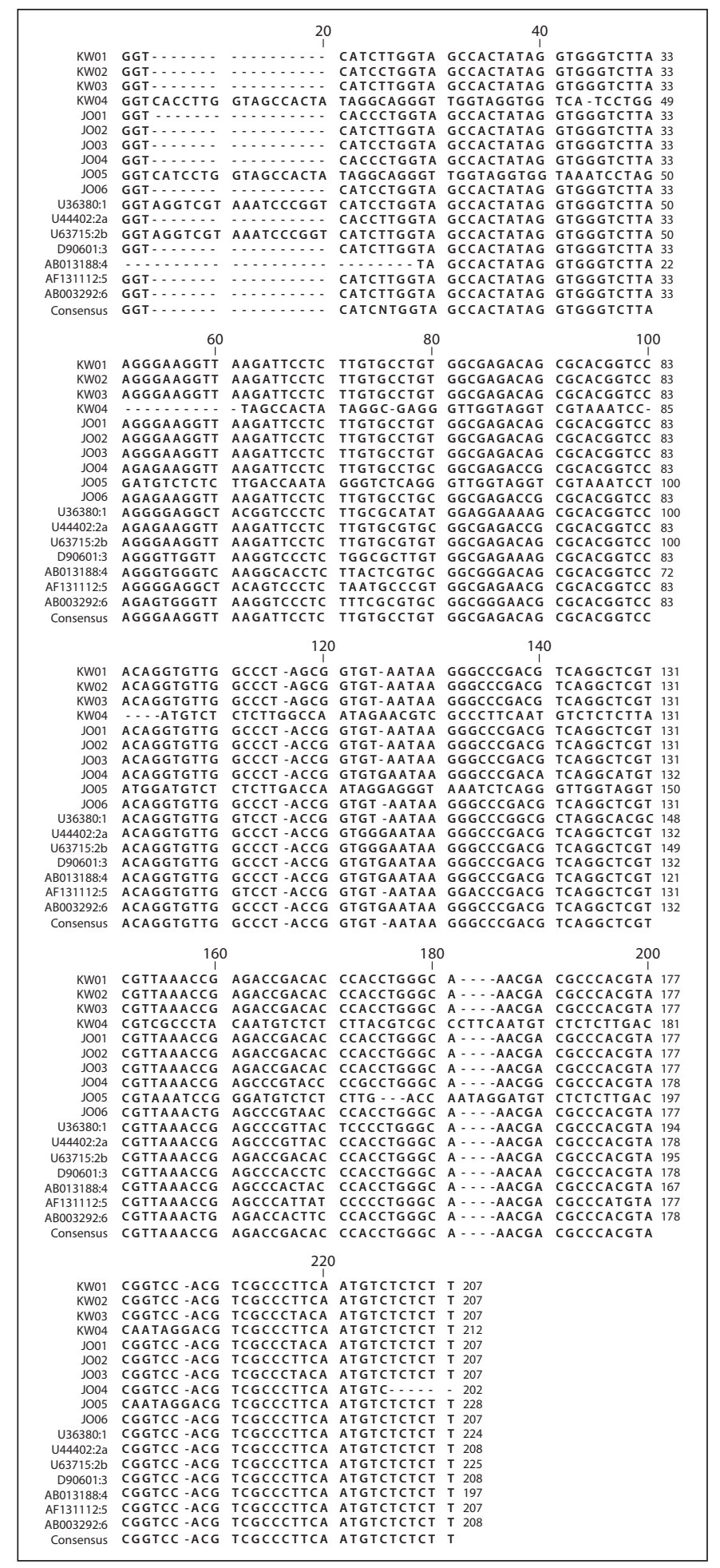

Fig. 1. Alignment of GBV-C 5'-UTR region sequences by MEGA4 freeware using the ClustalW method. Six Jordanians (JO) and 4 Kuwaitis (KW) were compared to the 6 known reference genotypes (U36380, U44402, D90601, AB013188, AF131112, and AB003292 representing genotypes 1 through 6, respectively). Dashes represent gaps.
GQ273924, GQ273925, GQ273926, GQ273927, and GQ273928, respectively) represent Jordanian clones, whereas sequences KW01 through KW04 (accession Nos. GQ273929, GQ273930, GQ273931, and GQ273932, respectively) represent Kuwaiti clones. Reference sequences representing GBV-C types 1-6 were used for phylogenetic comparisons [15]; accession Nos. U36380 (group 1); U44402 and D90600 (group 2a); U63715 (group 2b); D90601 and AB003288 (group 3); AB013188 and AB018667 (group 4); AF131112 and D50 (group 5), and AB003292 (group 6) in the GenBank of NCBI (National Center for Biotechnology Information). Other sequences from neighboring Middle Eastern countries were included for comparison purposes: Iran (IR1, IR2, IR4; accession Nos. EU714767, EU714768, EU714770, respectively) [8], Saudi Arabia (KSA; accession Nos. AF133506, AF133507, AF133508, AF133510, and AF133518) [4], and United Arab Emirates (UAE-1 through UAE-4) [7].

\section{Statistical Analysis}

Statistical analysis was carried out using $\chi^{2}$ test to compare proportions of positive samples between the two groups. Differences were considered to be statistically significant at $\mathrm{p}<0.05$.

\section{Results}

\section{Rate of Infection with $G B V-C$}

To find out the rate of infection of GBV-C, the researchers purified RNA from a total of 334 blood samples representing healthy blood donors from Kuwait and Jordan, and a portion of the 5'-UTR of the GBV-C genome was RT/nested PCR amplified. Of the 130 Kuwaiti samples, 32 were found to be positive for GBV-C RNA (24.6\%); 20 samples out of 204 samples from Jordanian donors were found to be positive $(9.8 \%)$. The two groups were significantly different from each other $(\mathrm{p}<0.05)$.

\section{Sequence Analysis}

PCR products of about 208 bp obtained with the nested PCR were considered positive for GBV-C. Further, PCR products representing a few of the healthy donors were randomly picked, cloned and sequenced.

The nucleotide sequences alignment of 6 Jordanian and 4 Kuwaiti isolates and the six published reference GBV-C sequences (U36380, U44402, D90601, AB013188, $\mathrm{AF} 131112$, and $\mathrm{AB} 003292$ representing genotypes 1 through 6 , respectively), are shown in figure 1. Nucleotide substitutions spread uniformly between aligned sequences, and with the exception of JO05 and KW04, variation between isolates was minimal. As for JO05 and KW04 sequences, we noticed major additions in several places; the two sequences were the least homologous to reference and experimental sequences. MEGA4 software can also perform pairwise distance homology analysis 
between any two sequences and between groups. Using this kind of analysis, we noticed that variation between any two isolates was less than $15 \%$ (data not shown), whereas this homology dropped to below $50 \%$ in the case of JO05 and KW04 isolates, and it was more pronounced in the KW04 sequence (data not shown).

\section{Phylogenetic Comparisons among the Healthy Groups}

As for the phylogenetic comparisons among the groups, with the exception of the two isolates $\mathrm{JO} 05$ and KW04, all sequences representing the randomly picked isolates belonged to group 2 (both $2 \mathrm{a}$ and $2 \mathrm{~b}$ ), which are prevalent in Europe and North America (figure 2 shows the results of the phylogenetic analysis). Finally, JO05 and KW04 were minimally homologous to any of the known reference sequences.

\section{Discussion}

The current study came as a sequel to a previous one conducted in the UAE [7]. This study was principally aimed at estimating and comparing the rates of infection of GBV-C in healthy blood donors in Kuwait and Jordan. Because both countries comprise diverse populations, only blood samples from their natives were screened. Screening samples for GBV-C, we noticed that the rates of infection were significantly different $(\mathrm{p}<0.05)$ between the two countries (24.6 and 9.8\% for Kuwaiti and Jordanian blood donors, respectively). The current results were higher than most of the previously reported serum RNA rates that ranged between 0.9 and $7 \%$ [3]. These results can also be compared to the $10 \%$ infection rate reported in Brazil, and the $14.6 \%$ found in Bolivia [9, 22]. Differences in the stated infection rates can be interpreted in many ways: the number of blood samples tested, method of detection used (antibody vs. PCR), and region amplified by PCR and primers used [6, 20, 23]. Also, geographic backgrounds of individuals tested, and the skills of technicians are other methods of interpretation [24, 25]. However, this can also be a genuine estimate that reflects modes of transmission and standard of living. In our case, a larger sample size needs to be tested before we make any conclusions about the prevalence of GBV-C in Kuwait and Jordan, which is beyond the scope of this pilot study.

Having accomplished our first aim, we put the second one to the test; sequence analysis (fig. 2), which was based on the conserved 5'-UTR region of GBV-C, representing 4 and 6 healthy Kuwaiti and Jordanian blood donors re-

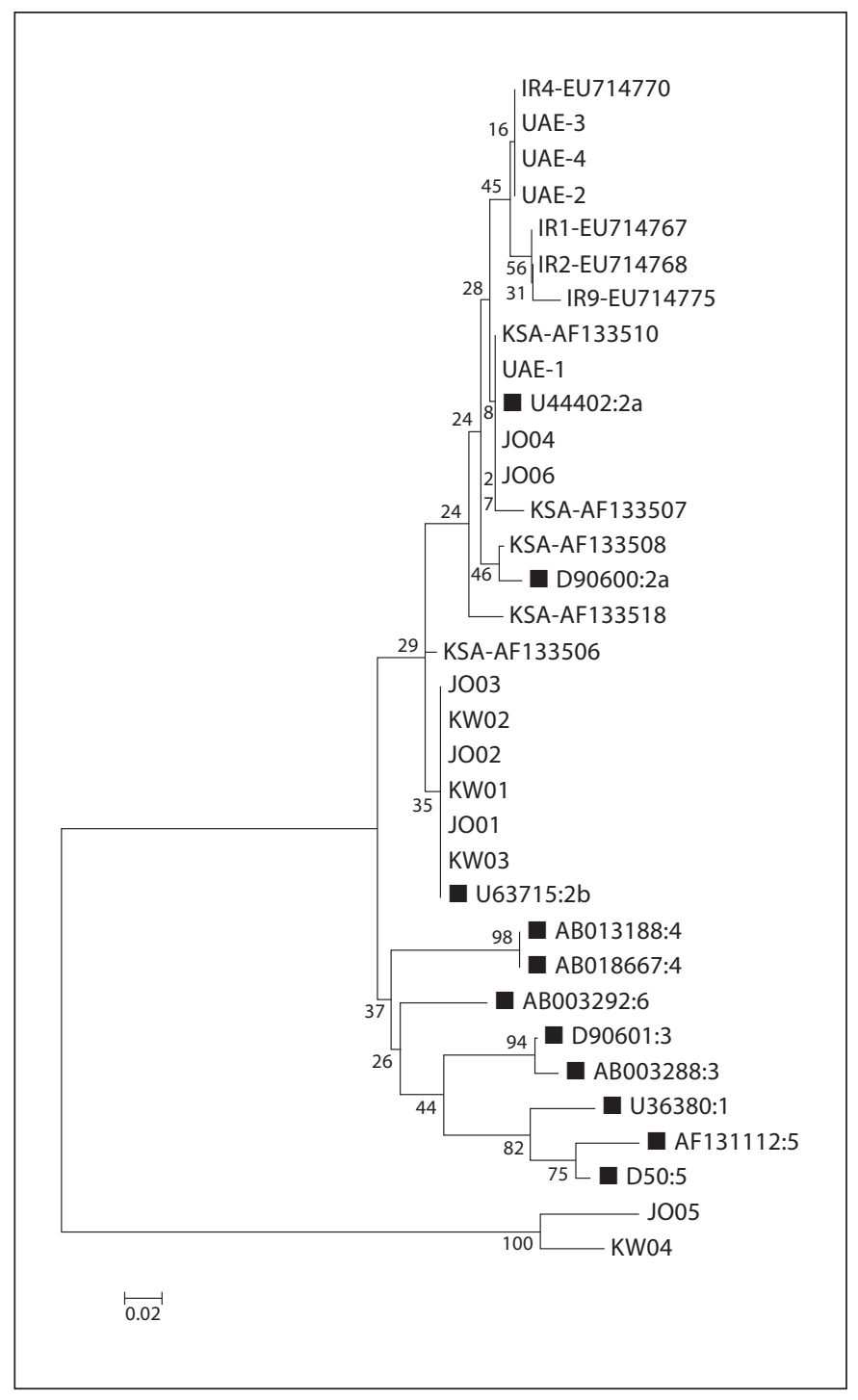

Fig. 2. Phylogenetic trees constructed using the neighbor-joining method of the GBV-C 5'-UTR. Sequences from 4 Kuwaiti (KW) and 6 Jordanian (JO) blood donors were compared to the 6 known genotypes (shown with filled squares). UAE, Iran (IR), and Saudi Arabia (KSA) sequences were included for comparison (see Materials and Methods). The horizontal bar indicates the number of nucleotide substitutions per site. Accession Nos. GQ273923, GQ273924, GQ273925, GQ273926, GQ273927, and GQ273928 represent Jordanian clones JO01-JO06, respectively; sequences KW01 through KW04 (accession Nos. GQ273929, GQ273930, GQ273931, and GQ273932, respectively) represent Kuwaiti clones. Accession Nos. for the reference sequences GBV-C types 1-6 used for phylogenetic comparisons were: U36380 (group 1), D90600 (group 2a), U63715 (group 2b), D90601 and AB003288 (group 3), AB013188 and AB018667 (group 4), AF131112 and D50 (group 5), and AB003292 (group 6). In addition, sequences from neighboring Middle Eastern countries were: Iran (IR1, IR2, IR4; accession Nos. EU714767, EU714768, EU714770, respectively), and Saudi Arabia (KSA; accession Nos. AF133506, AF133507, AF133508, AF133510, and AF133518). 
spectively, revealed the dominance of genotype 2 (European and North American genotype). Only one Jordanian (JO05) and one Kuwaiti (KW04) sequence deviated from this and did not belong to any of the 6 known genotypes used in previous studies, as shown by the phylogenetic data (fig. 2). This was not unexpected; the current sequences came from either Kuwaiti or Jordanian nationals, which should geographically belong to the Asian genotypes 3 or 4 . But because similar phylogenetic results were obtained in previous studies conducted in Middle Eastern countries neighboring both Kuwait and Jordan, UAE [7], Saudi Arabia [4] and Iran [8], where genotype 2 was also prevalent, we were more convinced that our results were genuine (as can be seen in the phylogenetic analysis).

This contradiction between geographic locations and GBV-C genotyping was also reported in other places; the Asian genotype 3 was reported to be prevalent in Bolivian blood donors, and genotype 5 (predominant in South Africa) was significantly predominant in Indonesia [22, 26]. In a more recent study, Loureiro et al. [24] reported the presence of an infecting Asiatic genotype (genotype 3) among Amerindians in Venezuela, and suggested an old origin of GBV-C/HGV. In another study, a unique and new subtype within genotype 1 (West African genotype) was reported in Japanese hemophiliacs [27]. Further, in another study of HGV, genotype 2 was reported to be spreading widely in Japan among homosexual men [28].

In most studies, as in the current one, the 5'-UTR was used for phylogenetic comparisons [9]. In the current study, the $208 \mathrm{bp}$ (from the $5^{\prime}$-UTR) PCR products from positive clones were used for sequencing.

As was stated in the Results section, MEGA4 analytical software includes a capability to perform pairwise distance calculations, which is an estimate of the evolutionary divergence between sequences (i.e. the number of base substitutions per site from analysis between se- quences). On closely re-examining the ten sequences using this tool, we noticed that six sequences (JO01 through JO03 and KW01 through KW03) actually had very minimal (1\%) divergence with genotype $2 \mathrm{~b}$ and $5 \%$ or less divergence with genotype $2 \mathrm{a}$. Further, sequences $\mathrm{JO} 04$ and JO06 were slightly more closely related to genotype $2 \mathrm{a}$. In contrast, sequences JO05 and KW04 homology to the 6 known genotypes was minimal (less than 50\%), with KW04 having more significant divergence than JO05. Finally, it was noted that the divergence between JO05 and KW04 was less than $30 \%$.

Overall, the current pilot study confirmed the presence of the GBV-C virus among Kuwaiti and Jordanian nationals at rates comparable to those previously reported in some regions of the world. Based on phylogenetic analyses, most of our GBV-C clones belonged to the North American/European genotype 2, although we may need to sequence a larger portion of the GBV-C genome in any future studies. Further studies using a larger number of blood samples from blood donors or other disease states may help give a more accurate and representative picture of the prevalence of this virus in the two countries. Finally, two isolates (JO05 and KW04) were obtained from two non-bordering countries (Jordan and Kuwait) that had sequences which did not belong to any of the known 6 genotypes. These two isolates warrant further sequence testing and may represent new GBV-C variants.

\section{Acknowledgements}

We are grateful to the staff of both Kuwait and Jordan Blood Transfusion Centers for providing the blood samples and would also like to thank Ms. Sinda Ezzedine (University of Sharjah) for her technical and administrative support. This project was supported by a grant from the University of Sharjah Research Center, Sharjah, UAE (Project No. 05-1022).

\section{References}

1 Simons JN, Leary TP, Dawson GJ, Pilot-Matias TJ, Muerhoff AS, Schlauder GG, Desai SM, Mushahwar IK: Isolation of novel viruslike sequences associated with human hepatitis. Nat Med 1995;1:564-569.

-2 Linnen J, Wages J Jr, Zhang-Keck ZY, Fry KE, Krawczynski KZ, Alter H, Koonin E, Gallagher M, Alter M, Hadziyannis S, Karayiannis P, Fung K, Nakatsuji Y, Shih JW, Young L, Piatak M Jr, Hoover C, Fernandez J, Chen S, Zou JC, Morris T, Hyams KC, Ismay S, Lif- son JD, Hess G, Foung SK, Thomas H, Bradley D, Margolis H, Kim JP: Molecular cloning and disease association of hepatitis $G$ virus: a transfusion-transmissible agent. Science 1996;271:505-508.

-3 Reshetnyak VI, Karlovich TI, Ilchenko LU: Hepatitis G virus. World J Gastroenterol 2008; 14:4725-4734.

4 Al-Ahdal MN, Rezeig MA, Kessie G, Chaudhry F, Al-Shammary FJ: GB virus C/ hepatitis $G$ virus infection in Saudi Arabian blood donors and patients with cryptogenic hepatitis. Arch Virol 2000;145:73-84.

$\checkmark 5$ Ramia S, Koussa S, Taher A, Haraki S, Klayme S, Sarkis D, Naman R: Hepatitis-Cvirus genotypes and hepatitis-G-virus infection in Lebanese thalassaemics. Ann Trop Med Parasitol 2002;96:197-202.

6 Cacoub P, Ohayon V, Sekkat S, Dumont B, Sbai A, Lunel F, Benslimane A, Godeau P, Archane MI: Epidemiologic and virologic study of hepatitis $\mathrm{C}$ virus infections in Mo- 
rocco (in French). Gastroenterol Clin Biol 2000;24:169-173.

-7 Abu Odeh RO, Al-Moslih MI, Al-Jokhdar MW, Ezzeddine SA: Detection and genotyping of GBV-C virus in the United Arab Emirates. J Med Virol 2005;76:534-540.

-8 Hekmat S, Mohraz M, Vahabpour R, Jam S, Bahramali G, Banifazl M, Aghakhani A, Eslamifar A, Mahboudi F, Edalat R, Ramezani A: Frequency and genotype of GB virus $C$ among Iranian patients infected with HIV. J Med Virol 2008;80:1941-1946.

9 Cheung RC, Keeffe EB, Greenberg HB: Hepatitis $G$ virus: is it a hepatitis virus? West J Med 1997;167:23-33.

10 Dawson GJ, Schlauder GG, Pilot-Matias TJ, Thiele D, Leary TP, Murphy P, Rosenblatt JE, Simons JN, Martinson FE, Gutierrez RA, Lentino JR, Pachucki C, Muerhoff AS, Widell A, Tegtmeier G, Desai S, Mushahwar IK: Prevalence studies of GB virus-C infection using reverse transcriptase-polymerase chain reaction. J Med Virol 1996;50:97-103.

-11 Smith DB, Cuceanu N, Davidson F, Jarvis LM, Mokili JL, Hamid S, Ludlam CA, Simmonds P: Discrimination of hepatitis G virus/GBV-C geographical variants by analysis of the $5^{\prime}$ non-coding region. J Gen Virol 1997;78:1533-1542.

12 Naito H, Win KM, Abe K: Identification of a novel genotype of hepatitis $G$ virus in Southeast Asia. J Clin Microbiol 1999;37:12171220.

13 Tucker TJ, Smuts H, Eickhaus P, Robson SC, Kirsch RE: Molecular characterization of the $5^{\prime}$ non-coding region of South African GBVC/HGV isolates: major deletion and evidence for a fourth genotype. J Med Virol 1999;59:52-59.

14 Sathar MA, York DF: Group 5: GBV-C/HGV isolates from South Africa. J Med Virol 2001; 65:121-122.
5 Muerhoff AS, Dawson GJ, Desai SM: A previously unrecognized sixth genotype of GB virus $C$ revealed by analysis of 5 -untranslated region sequences. J Med Virol 2006;78:105111.

16 Yoshiba M, Okamoto H, Mishiro S: Detection of the GBV-C hepatitis virus genome in serum from patients with fulminant hepatitis of unknown aetiology. Lancet 1995;346: 1131-1132.

17 Tucker TJ, Smuts HE, Eedes C, Knobel GD, Eickhaus P, Robson SC, Kirsch RE: Evidence that the GBV-C/hepatitis G virus is primarily a lymphotropic virus. J Med Virol 2000; 61:52-58.

18 George SL, Varmaz D, Stapleton JT: GB virus $\mathrm{C}$ replicates in primary $\mathrm{T}$ and $\mathrm{B}$ lymphocytes. J Infect Dis 2006;193:451-454.

19 Tillmann HL, Heiken H, Knapik-Botor A, Heringlake S, Ockenga J, Wilber JC, Goergen B, Detmer J, McMorrow M, Stoll M, Schmidt RE, Manns MP: Infection with GB virus C and reduced mortality among HIV-infected patients. N Engl J Med 2001;345:715-724.

20 Andonov A, Sauder C, Jacobsen H, Chaudhary R: Comparison of six sets of PCR primers from two different genomic regions for amplification of $\mathrm{GB}$ virus $\mathrm{C} /$ hepatitis $\mathrm{G}$ virus RNA. J Clin Microbiol 1998;36:286-289.

21 Tamura K, Dudley J, Nei M, Kumar S: MEGA4: Molecular Evolutionary Genetics Analysis (MEGA) software version 4.0. Mol Biol Evol 2007;24:1596-1599.

22 Konomi N, Miyoshi C, La Fuente Zerain C, Li TC, Arakawa Y, Abe K: Epidemiology of hepatitis $B, C, E$, and $G$ virus infections and molecular analysis of hepatitis $G$ virus isolates in Bolivia. J Clin Microbiol 1999;37:3291-3295.

-23 Souza IE, Allen JB, Xiang J, Klinzman D, Diaz R, Zhang S, Chaloner K, Zdunek D, Hess G, Williams CF, Benning L, Stapleton JT: Effect of primer selection on estimates of
GB virus C (GBV-C) prevalence and response to antiretroviral therapy for optimal testing for GBV-C viremia. J Clin Microbiol 2006;44:3105-3113.

-24 Loureiro CL, Alonso R, Pacheco BA, Uzcategui MG, Villegas L, Leon G, De Saez A, Liprandi F, Lopez JL, Pujol FH: High prevalence of $\mathrm{GB}$ virus $\mathrm{C} /$ hepatitis $\mathrm{G}$ virus genotype 3 among autochthonous Venezuelan populations. J Med Virol 2002;68:357-362.

25 Lefrere JJ, Lerable J, Mariotti M, Bogard M, Thibault V, Frangeul L, Loiseau P, Bouchardeau F, Laperche S, Pawlotsky JM, Cantaloube JF, Biagini P, de Lamballerie X, Izopet J, Defer C, Lepot I, Poveda JD, Dussaix E, Gerolami V, Halfon P, Buffet-Janvresse C, Ferec C, Mercier B, Marcellin P, MartinotPeignoux M, Gassain M: Lessons from a multicentre study of the detectability of viral genomes based on a two-round quality control of $\mathrm{GB}$ virus $\mathrm{C}$ (GBV-C)/hepatitis $\mathrm{G}$ virus (HGV) polymerase chain reaction assay. J Virol Methods 2000;85:117-124.

-26 Handajani R, Soetjipto, Lusida MI, Suryohudoyo P, Adi P, Setiawan PB, Nidom CA, Soemarto R, Katayama Y, Fujii M, Hotta H: Prevalence of GB virus C/hepatitis G virus infection among various populations in Surabaya, Indonesia, and identification of novel groups of sequence variants. J Clin Microbiol 2000;38:662-668.

27 Liu HF, Teng CW, Fukuda Y, Nakano I, Hayashi K, Takamatsu J, Goubau P, Toyoda $\mathrm{H}$ : A novel subtype of $\mathrm{GB}$ virus $\mathrm{C} /$ hepatitis $\mathrm{G}$ virus genotype 1 detected uniquely in patients with hemophilia in Japan. J Med Virol 2003;71:385-390.

28 Hattori J, Ibe S, Nagai H, Wada K, Morishita T, Sato K, Utsumi M, Kaneda T: Prevalence of infection and genotypes of GBV-C/HGV among homosexual men. Microbiol Immunol 2003;47:759-763. 